\title{
Risk stratification in patients with chronic heart failure by assessment of right ventricular isovolumic relaxation time using tissue Doppler imaging*
}

\author{
Vladimír Kincl, Jaroslav Meluzín, Lenka Špinarová, Petr Hude, Jan Krejčí, \\ Roman Panovský, Jiří Jarkovský*, Ladislav Dušek* \\ Ist Department of Internal Medicine/Cardioangiology, St. Anna Hospital, \\ ${ }^{*}$ Center of Biostatistics and Analyses, Masaryk University, Brno, Czech Republic
}

\begin{abstract}
Kincl V, Meluzín J, Špinarová L, Hude P, Krejčí J, Panovský R, Jarkovský J*, Dušek L* (Ist Department of Internal Medicine/Cardioangiology, St. Anna Hospital, *Center of Biostatistics and Analyses, Masaryk University, Brno, Czech Republic). Risk stratification in patients with chronic heart failure by assessment of right ventricular isovolumic relaxation time using tissue Doppler imaging. Cor Vasa 2006;48(9):305-310.
\end{abstract}

\begin{abstract}
Aim: The purpose of this study was to determine the importance of right ventricular isovolumic relaxation time (RV IVRT) measured by tissue Doppler imaging of tricuspid annular motion in the risk stratification in patients with chronic heart failure. Methods: In all, 108 patients with symptomatic heart failure and mean ejection fraction of $24 \%$ underwent standard echocardiographic examination, Doppler tissue imaging of tricuspid annular motion, and right-heart catheterization. The patients were followed up for a mean period of 18 months for cardiac-related death and non-fatal cardiac events including the implantation of a cardioverter/defibrillator and hospitalization for heart failure decompensation.

Results: The total number of cardiac events was $31 ; 12$ patients died, 19 had non-fatal cardiac event as described above. Statistical analysis showed significant differences in RV IVRT (98 \pm 62 vs $62 \pm 32 \mathrm{~ms} ; p<0.05)$, pulmonary artery pressure $(25.2 \pm 11.2$ vs $32.3 \pm 8.0 \mathrm{~mm} \mathrm{Hg} ; p<0.05)$, and pulmonary capillary wedge pressure $(17.0 \pm 9.1 \mathrm{vs} 23.5 \pm 7.3 \mathrm{~mm}$ $\mathrm{Hg} ; p<0.05$ ) between survivors and deceased patients. When analyzing the significance of parameters for prediction of event or death risk, mean pulmonary artery pressure (AP) and pulmonary capillary wedge pressure (PCW) were the only parameters significantly related to the risk of event (AP $p<0.001$; PCW $p<0.001$ ) or death (AP $p=0.009$; PCW $p=0.006$ ); nevertheless, a trend for RV IVRT ( $p=0.069)$ was found in predicting the risk of death.
\end{abstract}

Conclusion: The RV IVRT obtained by tissue Doppler imaging can only be used as an auxiliary method of risk stratification in patients with heart failure.

Key words: Tissue Doppler - Heart failure - Risk stratification

Kincl V, Meluzín J, Špinarová L, Hude P, Krejčí J, Panovský R, Jarkovský J*, Dušek L* (I. interní-kardioangiologická klinika, Fakultní nemocnice u sv. Anny, *Centrum biostatistiky a analýz Masarykovy univerzity, Brno, Česká republika). Stratifikace rizika u pacientů s chronickým srdečním selháním na základě stanovení izovolumického relaxačního času pravé komory tkáňovým dopplerovským zobrazením. Cor Vasa 2006;48(9):305-310.

Cíl: Cílem studie je stanovení významu izovolumického relaxačního času pravé komory (RV IVRT), měřeného pomocí tkáňového dopplerovského zobrazení pohybu trikuspidálního anulu při stratifikaci rizika u pacientů s chronickým srdečním selháním.

Soubor a metodika: Celkem 108 pacientů se symptomatickým srdečním selháním a průměrnou ejekční frakcí 24 \% podstoupilo standardní echokardiografické vyšetření, tkáňové dopplerovské zobrazení pohybů trikuspidálního anulu a pravostrannou srdeční katetrizaci. Pacienti byli dále sledováni po průměrnou dobu 18 měsíců s ohledem na kardiální úmrtí a nefatální kardiální př́ihody, jako je implantace kardioverteru-defibrilátoru a hospitalizace pro kardiální dekompenzaci. Výsledky: Celkový počet kardiálních př́ihod byl 31; 12 pacientů zemřelo, 19 mělo nefatální př́hodu. Statistická analýza ukázala signifikantní rozdíl RV IVRT (98 \pm 62 vs. $62 \pm 32 \mathrm{~ms} ; p<0,05)$, středního tlaku v plicnici (AP) $(25,2 \pm 11,2$ vs. $32,3 \pm 8,0 \mathrm{~mm} \mathrm{Hg} ; p<0,05)$ a tlaku v zaklínění v plicním řečišti (PCW) $(17,0 \pm 9,1$ vs. $23,5 \pm 7,3 \mathrm{~mm} \mathrm{Hg} ; p<0,05) \mathrm{mezi}$ zemřelými a žijícími pacienty. Analýza predikce rizika úmrtí či př́ihody ukázala, že AP a PCW byly jediné parametry $\mathrm{s}$ významným vztahem $\mathrm{k}$ riziku př́íhody (AP $p<0,001$; PCW $p<0,001$ ) a úmrtí (AP $p=0,009$; PCW $p=0,006$ ), i když jistý trend pro RV IVRT $(p=0,069)$ byl nalezen pro predikci úmrtí avšak bez dosažení statistické významnosti.

Závěr: RV IVRT stanovené pomocí tkáňového dopplerovského zobrazení lze použít jen jako pomocnou metodu při stratifikaci rizika u pacientů se srdečním selháním.

Klíčová slova: Tkáňové dopplerovské vyšetření - Srdeční selhání - Stratifikace rizika

Address: MUDr. Vladimír Kincl, Ist Department of Internal Medicine/Cardioangiology, St. Anna Hospital, Pekařská 53, 65691 Brno, Czech Republic, e-mail: v.kincl@centrum.cz

*Supported in part by a grant of the Ministry of Education of the Czech Republic (MSM, No 0021622402). 
Despite significant progress in pharmacological and surgical therapy, the prognosis with chronic heart failure remains poor, and the 1-year survival of selected patient populations may even fall below 50\%. ${ }^{(1-3)}$ Right ventricular systolic and diastolic dysfunction are powerful markers of a poor prognosis or non-fatal cardiac events in patients with congestive heart failure. Previously, assessment of right ventricular function was performed mostly by radionuclide ventriculography ${ }^{(4-6)}$ or by the thermodilution technique during right-heart cathetrization. ${ }^{(7-9)}$ There are only few studies using tissue Doppler imaging (TDI) for the assessment of prognosis and risk stratification in patients with heart failure. ${ }^{(10,11)}$ In our previous reports, ${ }^{(12,13)}$ we focused on tricuspid annular velocities and found that the combination of right ventricular systolic and diastolic functional parameters (Doppler RV index, myocardial acceleration during isovolumic contraction, peak tricuspid systolic annular velocity, peak early diastolic tricuspid annular velocity) represents a very powerful tool for risk stratification of patients with symptomatic heart failure. However, we did not study the impact of right ventricular isovolumic relaxation time (RV IVRT).

Right ventricular isovolumic relaxation time measured by tissue Doppler imaging of tricuspid annular motion was previously used to assess right atrial pressure, ${ }^{(14)}$ left ventricular filling pressures, ${ }^{(15,16)}$ and pulmonary artery systolic pressure. ${ }^{(17-20)}$

In this study, we studied the prognostic importance of RV IVRT in patients with heart failure alone or in combination with other previously reported tissue Doppler variables-Doppler RV index (Tei index) and myocardial acceleration during isovolumic contraction (IVA). ${ }^{(11)}$

\section{METHODS}

\section{Study population}

The study included 108 patients with symptomatic heart failure (New York Heart Association Class II-IV) admitted to our department for comprehensive cardiologic investigation. They were 90 (83\%) men with a mean age of 52 years (range, 23-63 years). The mean left ventricular ejection fraction was $24 \%$ (range, 12-39\%). Thirty-six (33\%) patients had hypertension, 61 (56\%) hypercholesterolemia, $20(19 \%)$ patients were treated for diabetes mellitus. The majority of patients were classified in NYHA Class III $(70 \%)$ or IV (3\%), with only $27 \%$ being in NYHA Class II.

The inclusion criteria were as follows: (1) sinus rhythm on electrocardiography (ECG); (2) good quality of echocardiographic images allowing measurement of tricuspid annular motion velocities and time intervals; (3) absence of an acute coronary event in the last three months; (4) absence of a malignant disease or advanced liver, renal or lung disorder; (5) no need for myocardial revascularization or urgent heart transplantation.

Clinically unstable patients on hospital admission (resting dyspnea, need for parenteral diuretics or catecholamines, ankle edema, rales on lung auscultation) were investigated and enrolled into the study after cardiac compensation.
The heart failure was caused by ischemic heart disease $(\geq 70 \%$ narrowing of the diameter of at least one major coronary artery, as assessed by coronary angiography, or documented myocardial infarction - 59 patients) or idiopathic dilated cardiomyopathy (49 patients). Patients with valvular or congenital heart disorders were excluded. Idiopathic dilated cardiomyopathy was diagnosed on the basis of echocardiography, ECG (absence of $\mathrm{Q}$ waves) and clinical criteria; patients over 40 years with risk factors of coronary artery disease had only coronary angiography.

Before entering the study, patients had their pharmacological therapy optimized. A total of 103 (95\%) patients were taking an angiotensin-converting enzyme (ACE) inhibitor, 76 (70\%) digitalis, 107 (99\%) furosemide, 77 (71\%) spironolactone, and 81 (75\%) beta-blockers.

All patients underwent physical examination, routine blood chemistry and hematologic measurements, 12-lead ECG, chest X-ray, standard echocardiography, TDI of tricuspid annular motion, and right-heart catheterization. All patients also gave their written informed consent to the investigation, and the study was approved by the institutional ethics committee.

\section{Echocardiography}

Standard echocardiographic examination and pulsed TDI of tricuspid annular motion were performed in all patients. We used a SONOS 5500 system (Hewlett-Packard, Andover, Mass, USA) equipped with TDI technology. TDI measurement was performed with patients in the left lateral decubitus position. Guided by the 2-dimensional apical 4-chamber view, a sample volume was placed on the tricuspid annulus at the site of attachment of the anterior leaflet of the tricuspid valve. The examination with simultaneous ECG was recorded on videotape (VHS) at a speed of $50 \mathrm{~mm} / \mathrm{s}$ for further analysis.

Peak velocity of isovolumic contraction (Sa'), time to reach this velocity (t'), and right ventricular isovo-

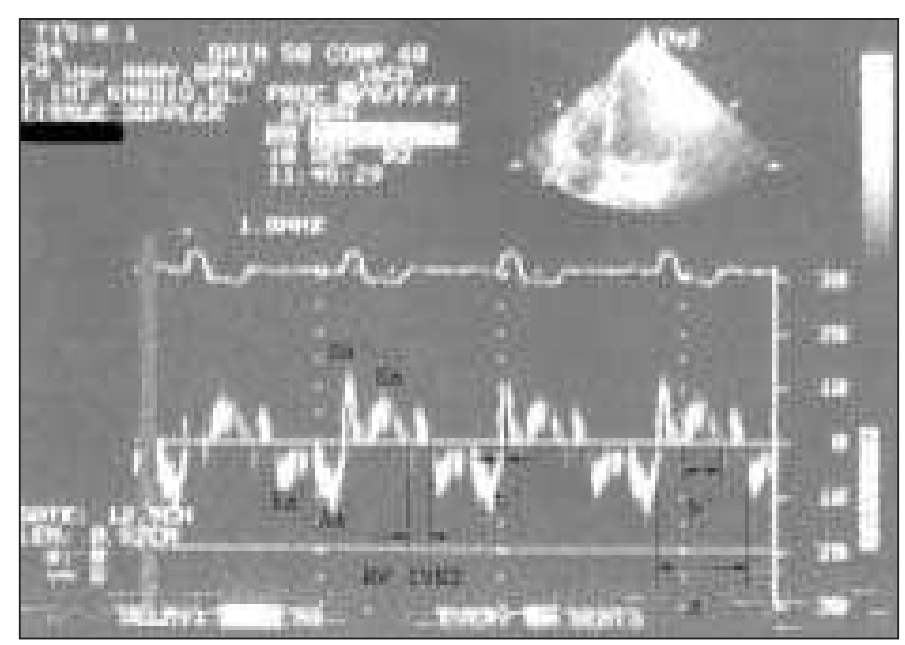

Figure 1 Sa'- peak velocity of isovolumic contraction, t'- time between the baseline and the peak velocity during isovolumic contraction, a'- time interval between the end and the onset of tricuspid annular diastolic velocities, b'- duration of tricuspid annular systolic ejection, Ea - peak early diastolic tricuspid annular velocity, Aa - peak late diastolic tricuspid annular velocity, $\mathrm{Sa}$ - peak tricuspid annular velocity during systolic ejection 
lumic relaxation time (RV IVRT) were measured, and the right ventricular Doppler index (Tei index) and IVA were calculated as described elsewhere. ${ }^{(13)}$ Doppler measurement is demonstrated in Figure 1. Measurement of time intervals was performed off-line from VHS videotapes on the SONOS 5500 using trailing edge methodology by an experienced observer. All parameters were measured from three heart cycles and the mean value was calculated. In addition to pulsed TDI, standard echocardiography was performed including M-mode, 2-dimensional, and pulsed and color Doppler echocardiography. Left ventricular ejection fraction was calculated according to modified Simpson's rule.

\section{Right-heart catheterization}

All patients underwent right-heart catheterization within 24 hours of echocardiography. The examination was performed via the right subclavian vein or the right jugular vein. A $7 \mathrm{~F}$ thermodilution catheter (model 131HF7, Baxter Healthcare Corp, Irvine, Calif, USA) was advanced through right-heart cavities and placed in the pulmonary capillary wedge position. Measurements of mean central venous pressure (CVP), mean pulmonary artery pressure (AP), and mean pulmonary capillary wedge pressure (PCW) were obtained with patients in the supine position. A mechanoelectric transducer (model P23XL, Ohmeda Medical Devices Division, Oxnard, Calif, USA) was used. Cardiac output was measured by the thermodilution technique.

\section{Follow-up}

The patients were followed up for cardiac mortality and non-fatal cardiac events related to heart failure such as hospitalization for cardiac decompensation or need for cardioverter/defibrillator implantation due to malignant ventricular arrhythmias. Cardiac death was defined as death caused by congestive heart failure, myocardial infarction or cardiac arrest.

In patients dying outside our hospital in whom an autopsy was not performed, a sudden unexpected death (within 1 hour of the onset of symptoms) was ascribed to a cardiac cause.

Cardiac decompensation requiring admission to hospital was defined by dyspnea, need for parenteral diuretics and clinical signs of left (rales on lung auscultation, gallop) and/or right (neck vein distension, ankle edema, hepatomegaly) heart failure.

There was only one cardiac event taken into consideration in each patient in the following hierarchy: death $>$ need for implantation of a cardioverter/defibrilator $>$ hospitalization for heart failure. Event-free survival was defined as survival without a combined end-point (cardiac death, need for implantation of a cardioverter/defibrillator, hospitalization for heart failure). The mean follow-up period was 18 months (range, 1-48 months).

\section{Statistical analysis}

No case was excluded before the analyses. A $p$ value less than 0.05 was taken as a limit for statistical significance in all univariate and multivariate analyses. Standard descriptive statistics was used to express differences among subgroups of cases (mean supplied with standard deviation and 95\% confidence intervals). Statistical significance of differences in continuous parameters between groups of patients was tested by the Mann-Whitney U test. Predictive potential of parameters was analyzed using Cox regression. The analyses were performed using Statistica 7 for Windows.

Table I

\begin{tabular}{llllll}
\hline \hline & $\begin{array}{l}\text { Whole } \\
\text { population }\end{array}$ & $\begin{array}{l}\text { Patients without } \\
\text { cardiac events }\end{array}$ & $\begin{array}{l}\text { Patients with } \\
\text { cardiac events }\end{array}$ & $\begin{array}{l}\text { Living } \\
\text { patients }\end{array}$ & $\begin{array}{l}\text { Deceased } \\
\text { patients }\end{array}$ \\
\hline Sample size & 108 & 77 & 31 & 96 & 12 \\
\hline Men & 90 & 64 & 26 & 78 & 12 \\
\hline Women & 18 & $52(8)$ & $50(7)$ & $52(8)$ & $52(8)$ \\
\hline Age (years) & $52(8)$ & $97(58)$ & $87(66)$ & $98(62)$ & $62(32)$ \\
\hline RV IVRT (ms) & $94(61)$ & {$[83.64 ; 109.84]$} & {$[63.27 ; 110.15]$} & {$[85.41 ; 110.38]+$} & {$[42.69 ; 80.48]+$} \\
\hline IVA (m/s) & {$[82.38 ; 105.34]$} & $2.89(1.20)$ & $2.85(1.28)$ & $2.91(1.25)$ & $2.62(0.97)$ \\
& $2.88(1.23)$ & {$[2.62 ; 3.16]$} & {$[2.39 ; 3.31]$} & {$[2.66 ; 3.16]$} & {$[2.04 ; 3.2]$} \\
\hline TEI & {$[2.64 ; 3.11]$} & $1.00(0.31)$ & $1.17(0.55)$ & $1.04(0.41)$ & $1.11(0.31)$ \\
& $1.05(0.40)$ & {$[0.93 ; 1.07]$} & {$[0.97 ; 1.36]$} & {$[0.96 ; 1.12]$} & {$[0.93 ; 1.29]$} \\
\hline CVP (mm Hg) & $6.97 ; 1.13]$ & $6.1(4.7)$ & $6.3(4.6)$ & $6.0(4.7)$ & $6.9(4.8)$ \\
& {$[5.2 ; 7.04]$} & {$[4.96 ; 7.15]$} & {$[4.56 ; 8]$} & {$[5.05 ; 6.99]$} & {$[3.96 ; 9.86]$} \\
\hline AP (mm Hg) & $25.9(11.1)$ & $24.0(11.0)$ & $30.8(9.6)$ & $25.2(11.2)$ & $32.3(8.0)$ \\
& {$[23.78 ; 28.04]$} & {$[21.46 ; 26.49]^{*}$} & {$[27.27 ; 34.26]^{*}$} & {$[22.9 ; 27.44]+$} & {$[27.32 ; 37.22]+$} \\
\hline PCW (mm Hg) & $17.7(9.2)$ & $15.8(9.8)$ & $22.5(7.5)$ & $17.0(9.1)$ & $23.5(7.3)$ \\
& {$[15.94 ; 19.47]$} & {$[13.76 ; 17.84]^{*}$} & {$[19.58 ; 25.36]^{*}$} & {$[15.16 ; 18.88]+$} & {$[19.03 ; 28.06]+$} \\
\hline PVR (dyn.cm $\left.{ }^{5}\right)$ & $163(105)$ & $156(99)$ & $179(117)$ & $160(107)$ & $183(84)$ \\
& {$[142.54 ; 182.95]$} & {$[133.65 ; 178.91]$} & {$[136.34 ; 221.46]$} & {$[138.62 ; 182.15]$} & {$[130.72 ; 235.1]$} \\
\hline \hline
\end{tabular}

Data are shown as a mean (standard deviation) and [95\% confidence intervals], RV IVRT - right ventricular isovolumic relaxation time, TEI - right ventricular Tei index, IVA - tricuspid annular acceleration during isovolumic contraction, CVP - central venous pressure, AP - pulmonary artery pressure, PCW - pulmonary capillary wedge pressure, PVR - pulmonary vascular resistance, ${ }^{*}$ - statistical significance $(p<0.05)$ between groups of patients with and without cardiac events, +- statistical significance $(p<0.05)$ between groups of living and deceased patients. 
Table II

Predictive potential of parameters in univariate Cox regression models (* - a statistically significant parameter $[<0.05]$ )

\begin{tabular}{|c|c|c|c|c|}
\hline & Event-fre & & Overall su & \\
\hline & Relative risk (95\% CI) & $p$ & Relative risk (95\% CI) & $p$ \\
\hline IVRT & $1.00(0.99 ; 1.00)$ & 0.585 & $0.99(0.98 ; 1.00)$ & 0.069 \\
\hline IVA & $1.07(0.80 ; 1.43)$ & 0.654 & $0.85(0.47 ; 1.53)$ & 0.578 \\
\hline TEI & $1.82(0.93 ; 3.56)$ & 0.079 & $1.27(0.40 ; 4.08)$ & 0.683 \\
\hline CVP & $1.04(0.97 ; 1.12)$ & 0.291 & $1.06(0.95 ; 1.18)$ & 0.314 \\
\hline $\mathrm{AP}$ & $1.07(1.03 ; 1.10)$ & 0.000* & $1.08(1.02 ; 1.14)$ & 0.009* \\
\hline PCW & 1.09 (1.05; 1.14) & 0.000* & $1.10(1.03 ; 1.18)$ & $0.006^{*}$ \\
\hline PVR & $1.00(1.00 ; 1.01)$ & 0.072 & $1.00(1.00 ; 1.01)$ & 0.205 \\
\hline
\end{tabular}

IVRT - isovolumic relaxation time, IVA - tricuspid annular acceleration during isovolumic contraction, TEI - right ventricular Tei index, CVP - central venous pressure, AP - pulmonary artery pressure, PCW - pulmonary capillary wedge pressure, PVR - pulmonary vascular resistance, ${ }^{*}$ - statistical significance $(p<0.05)$ between groups of patients with and without cardiac events.

\section{RESULTS}

\section{Clinical, echocardiographic and right-heart catheterization variables}

Table I compares the clinical, echocardiographic and hemodynamic variables in the whole patient population, in patients with and without all cardiac events, and in living patients or in deceased patients.

Patients with cardiac death as well as those with the combined endpoint had significantly higher pulmonary artery pressure (AP) and pulmonary capillary wedge pressure (PCW). RV IVRT was significantly lower only in deceased patients. Deceased patients also had higher Tei index, lower IVA, higher central venous pressure and pulmonary vascular resistance, though not reaching statistical significance.

\section{Follow-up data}

Of the total number of 108 patients, 31 had a cardiac event. We documented 12 cardiac-related deaths and 19 non-fatal cardiac events; 16 patients were hospitalized for heart failure decompensation, and 3 for the need for cardioverter/defibrillator implantation. No patient underwent myocardial revascularization during follow-up.

\section{Death or event risk prediction}

All the above variables were analyzed in Cox regression models to determine their predictive potential. When analyzing the significance of parameters for predicting the risk of an event or death, AP and PCW were the only parameters related significantly to event or death risk $(p<0.01)$; nevertheless, a trend for IVRT was found in predicting the risk of death, but without statistical significance $(p=0.069)$ (Table II). The analysis showed a relatively low predictive potential of non-invasive methods evaluated in this study for predicting event-free or overall survival. A significant relationship (yet without enough strength for predicting a non-fatal event or death) was found between event-free survival and TEI and overall survival and IVRT, which suggests some connection between these parameters. However, the $p$ values of the whole model combining IVRT, IVA, and TEI were 0.222 for event-free survival and 0.078 for survival (Table III).

A combination of invasive and non-invasive parameters (AP, PCW and IVRT) shows better
Table III

Predictive potential of IVRT parameter together with IVA and TEI parameters in Cox regression models (* - a statistically significant parameter $[p<0.05])$

\begin{tabular}{lcc}
\hline \hline \multicolumn{2}{l}{ Event-free survival $\left(\chi^{2}=4.397, p=0.222\right)$} & \\
& Relative risk $(95 \% \mathrm{CI})$ & $p$ \\
\hline TEI & $2.26(1.07 ; 4.76)$ & $\mathbf{0 . 0 3 3 ^ { * }}$ \\
IVA & $1.04(0.78 ; 1.39)$ & 0.801 \\
IVRT & $1.00(0.99 ; 1.00)$ & 0.217 \\
& & \\
Overall survival $\left(\chi^{2}=6.814, p=0.078\right)$ & $p$ \\
& Relative risk $(95 \% \mathrm{CI})$ & 0.109 \\
TEI & $3.20(0.77 ; 13.23)$ & 0.538 \\
IVA & $0.84(0.47 ; 1.48)$ & $\mathbf{0 . 0 2 8}$ \\
IVRT & $0.98(0.97 ; 1.00)$ & \\
\hline \hline
\end{tabular}

TEI - right ventricular Tei index, IVA - tricuspid annular acceleration during isovolumic contraction, IVRT - isovolumic relaxation time

Table IV

Predictive potential of IVRT parameter together with $\mathrm{AP}$ and PCW parameters in Cox regression models $(*-$ statistically significant parameter $[p<0.01])$

\begin{tabular}{|c|c|c|}
\hline \multicolumn{3}{|c|}{ Event-free survival $\left(\chi^{2}=18.274, p=0.0004^{*}\right)$} \\
\hline $\mathrm{AP}$ & $0.98(0.89 ; 1.08)$ & 0.725 \\
\hline PCW & $1.11(0.99 ; 1.25)$ & 0.069 \\
\hline IVRT & $1.00(0.99 ; 1.00)$ & 0.624 \\
\hline \multicolumn{3}{|c|}{ Overall survival ( $\left.\chi^{2}=12.463, p=0.0059 *\right)$} \\
\hline & Relative risk (95\% CI) & $p$ \\
\hline $\mathrm{AP}$ & $1.06(0.91 ; 1.24)$ & 0.471 \\
\hline PCW & $1.03(0.86 ; 1.24)$ & 0.748 \\
\hline IVRT & $0.99(0.97 ; 1.00)$ & 0.058 \\
\hline
\end{tabular}

AP - pulmonary artery pressure, PVR - pulmonary vascular resistance, IVRT - isovolumic relaxation time, * - statistical significance $(p<0.05)$ between groups of patients with and without cardiac events.

results. Although the resulting $p$ values of considered parameters do not show a high degree of predictive power, the overall significance of both models indicates these models provide useful information. The $p$ values are 0.0004 for event-free survival and 0.0059 for overall survival. It seems that there is no individual strong predictive para- 
meter, but that the parameters complement each other (Table IV).

\section{DISCUSSION}

Previous studies ${ }^{(11,21,22)}$ identified few TDI parameters (peak tricuspid systolic annular velocity - Sa, peak early diastolic tricuspid annular velocity - Ea, peak late diastolic annular velocity - Aa) describing systolic and diastolic function of the right ventricle. Sa reflects RV systolic function. It correlates significantly with RV ejection fraction assessed by radionuclide ventriculography ${ }^{(21)}$ and a significant inverse relationship between Sa and pulmonary artery pressure has been observed. ${ }^{(21)}$ However, Sa is significantly afterload-dependent; $\mathrm{Ea}$ and the $\mathrm{Ea} / \mathrm{Aa}$ ratio have been investigated as markers of RV diastolic function, and many diseases or syndromes including heart failure, systemic hypertension, Chagas disease and arrhythmogenic dilated cardiomyopathy have been shown to be associated with significant decreases in Ea and Ea/Aa. ${ }^{(21-24)}$

There are also two combined indexes successfully used for RV function, i.e., IVA and the Doppler RV index (Tei index). IVA reflects RV systolic function during isovolumic contraction and is relatively preload- and afterload-independent. The Tei index shows global RV function. It is not significantly influenced by heart rate, RV pressure, RV dilatation or tricuspid regurgitation, ${ }^{(25)}$ but all individual components forming this index (ejection time, isovolumic contraction time and isovolumic relaxation time) were found to be heart rate-dependent. ${ }^{(25)}$

RV IVRT has been shown to be inversely related to mean right atrial pressure (RAP) independent of the effect of RV end-diastolic or pulmonary artery pressure. ${ }^{(14)}$ In view of the fact that RAP reflects both left- and right-sided heart function, it has diagnostic and prognostic significance in patients with cardiac diseases, especially with heart failure. When right atrium fails or is volume overloaded, RAP increases with an earlier tricuspid valve opening, so that RV IVRT shortens. ${ }^{(18)}$ RV IVRT has also been used to predict pulmonary artery systolic pressure (PA), because it increases proportionally with PA when RAP is normal. ${ }^{(18)}$ In previous studies, RV IVRT was measured by phonocardiography and pulse tracing ${ }^{(17)}$ or combined Doppler echocardiography and phonocardiography, ${ }^{(18)}$ M-mode recordings of pulmonic and tricuspid valves, ${ }^{(19)}$ and Doppler echocardiography. ${ }^{(20)}$

In this study, we tried to use RV IVRT, as measured by TDI and its combination with other parameters, to evaluate its importance in assessing the prognosis of patients with chronic heart failure and to identify the most powerful combination of these variables for this purpose.

Our results show that RV IVRT is significantly shorter in patients with cardiac-related death; however, its predictive potential does not reach statistical significance in contrast with invasively measured hemodynamic parameters (pulmonary artery pressure and pulmonary capillary wedge pressure) exhibiting a significant predictive potential. This may be due to the relatively small number of patients because a trend in death prediction was found for RV IVRT. Also, in contrast to results reported elsewhere, ${ }^{(1)}$ the Tei index and IVA did not show statistical significance in survival or event-free survival prediction in this study.

Based on these results, we can conclude that RV IVRT obtained using TDI can only be used as an auxiliary parameter in the risk stratification of patients with chronic heart failure. However, stronger prognostic data can be obtained by right-heart catheterization because the combination of RV IVRT, AP and PCW shows a significant predictive potential as do AP and PCW alone.

\section{REFERENCES}

1. Shah MR, Hasselblad V, Gheorghiade M, et al. Prognostic usefulness of the six-minute walk in patients with advanced congestive heart failure secondary to ischemic or nonischemic cardiomyopathy. Am J Cardiol 2001;88:987-93.

2. Morley D, Brozena SC. Assessing risk by hemodynamic profile in patients awaiting cardiac transplantation. Am J Cardiol 1994;73:379-83.

3. Aaronson KD, Schwartz JS, Chen TM, Wong KL, Coin JE, Mancini DM. Development and prospective validation of a clinical index to predict survival in ambulatory patients referred for cardiac transplant evaluation. Circulation 1997;95:2660-7.

4. Di Salvo TG, Mathier M, Semigran MJ, Dec GW. Preserved right ventricular ejection fraction predicts exercise capacity and survival in advanced heart failure. J Am Coll Cardiol 1995;25:1143-53.

5. De Groote P, Millaire A, Foucher-Hossein C, et al. Right ventricular ejection fraction is an independent predictor of survival in patients with moderate heart failure. J Am Coll Cardiol 1998;32:948-54.

6. Polak JF, Holman L, Wynne J, Colucci WS. Right ventricular ejection fraction: an indicator of increased mortality in patients with congestive heart failure associated with coronary artery disease. J Am Coll Cardiol 1983;2:217-24.

7. Ghio S, Gavazzi A, Campana C, et al. Independent and additive prognostic value of right ventricular systolic function and pulmonary artery pressure in patients with chronic heart failure. J Am Coll Cardiol 2001; 37:183-8

8. Gavazzi A, Berzuini C, Campana C, et al. Value of right ventricular ejection fraction in predicting short-term prognosis of patients with severe chronic heart failure. J Heart Lung Transplant 1997;16:774-85.

9. Juilliére Y, Barbier G, Feldmann L, Grentzinger A, Danchin N, Cherrier F. Additional predictive value of both left and right ventricular ejection fractions on long-term survival in idiopathic dilated cardiomyopathy. Eur Heart J 1997; 18:276-80.

10. Meluzín J, Špinarová L, Dušek L, Toman J, Hude P, Krejčí J. Prognostic importance of the right ventricular function assessed by Doppler tissue imaging. Eur $\mathrm{J}$ Echocardiogr 2003;4:262-71.

11. Meluzín J, Śpinarová L, Hude P, et al. Prognostic importance of various echocardiographic right ventricular functional parameters in patients with symptomatic heart failure. J Am Soc Echocardiogr 2005;18:435-44.

12. Špinarová L, Toman J, Meluzín J, et al. Je funkce pravé komory důležitá pro prognózu pacientů s chronickým srdečním selháním? Cor Vasa 2005:47;47:33-7.

13. Meluzín J, Eisenberger M. Echokardiografické hodnocení funkce pravé komory. Cor Vasa 2003;45:492-500.

14. Abbas A, Lester S, Moreno FC, Komandoor S, Fortuin D, Appleton C. Noninvasive assesment of right atrial pres- 
sure using Doppler tissue imaging. J Am Soc Echocardiogr 2004; 17:1155-60.

15. Mulwagh S, Quinones MA, Kleiman NS, Cheirif J, Zoghbi WA. Estimation of left ventricular end diastolic pressure from Doppler transmitral flow velocity in cardiac patients independent of systolic performance. J Am Coll Cardiol 1992;20:112-9.

16. Rivas-Gotz C, Khoury DS, Manolios M, Rao L, Kopelen M, Nagueh SF. Time interval between onset of mitral inflow and onset of early diastolic velocity by tissue Doppler: a novel index of left ventricular relaxation. J Am Coll Cardiol 2003;42:1 163-70.

17. Burstin L. Determination of pressure in the pulmonary artery by external graphic recordings. Br Heart $\mathrm{J}$ 1967;29:396-404.

18. Hatle L, Angelsen BA, Tromsdal A. Non-invasive estimation of pulmonary artery systolic pressure with Doppler ultrasound. Br Heart J 1981;45:157-65.

19. Stevenson JG. Comparison of several noninvasive methods for estimation of pulmonary artery pressure. J Am Soc Echocardiogr 1989;2:157-71

20. Chan KL, Currie PJ, Seward JB, Hagler DJ, Mair DD, Tajik AJ. Comparison of three Doppler ultrasound methods in the prediction of pulmonary artery pressure. J Am Coll Cardiol 1987;9:549-54.
21. Meluzín J, Špinarová L, Bakala J, et al. Pulsed Doppler tissue imaging of the velocity of tricuspid annular systolic motion: a new, rapid and non-invasive method of evaluating right ventricular systolic function. Eur Heart J 2001;22:340-8.

22. Cicala S, Galderisi M, Caso P, et al. Right ventricular diastolic dysfunction in arterial systemic hypertension: analysis by pulsed Doppler tissue imaging. Eur $J$ Echocardiogr 2002;3:135-42.

23. Barros MVL, Machado FS, Ribeiro ALP, Rocha MOC. Detection of early right ventricular dysfunction in Chagas' disease using Doppler tissue imaging. J Am Soc Echocardiogr 2002;15:1197-201.

24. Lindström L, Wilkenshoff UM, Larsson H, Wranne B. Echocardiographic assessment of arrhythmogenic right ventricular cardiomyopathy. Heart 2001;86:31-8.

25. Tei Ch, Dujardin KS, Hodge DO, et al. Doppler echocardiographic index for assessment of global right ventricular function. J Am Soc Echocardiogr 1996;9: 838-47.

Received 6 June 2006

Revision accepted 14 June 2006 